\title{
KEY FEATURES OF GOVERNANCE IN BRAZILIAN SCIENCE AND TECHNOLOGY PARKS
}

\begin{abstract}
The situation of Brazilian Science and Technology Parks (STPs) operation led to the field research. Even with the public policy of stimulus and support of associations, nothing has been mapped on the dissemination of results (economic growth and regional development). This scenario instigates the question: What are the governance characteristics of Brazilian Science and Technology Parks? A empirical field research was developed, taking into consideration the possibility of replication trought the registration of the choice criteria in the multiple cases and trought research detalhes and data colection. Eight STPs (TECNOPUC - Porto Alegre, Valetec - Novo Hamburgo, Tecnosinos Sao Leopoldo, Unicamp, CIATEC and TECHNOPARK - Campinas, Rio Park - Rio de Janeiro and SergipeTec) participated in research. The results and considerations about the research question allows to infer the little effectiveness of governance (without qualitative or quantitative performance indicators) is possibly caused by tensions characterized by elements such as heterogeneity in characteristics of organizations that are part of STPs, lack of consensus on common goals, pressure forces and influences affecting trusts, nonconformity standards and personal and organizational preferences. Leadership relations championed by the government and / or companies can negatively influence the STP's performance as a whole.
\end{abstract}

Keywords: Regional Economic Development; Science and Technology Parks; Governance; Effectiveness.

\section{PRINCIPAIS CARACTERÍSTICAS DA GOVERNAÇÃO NAS PARQUES DE CIÊNCIA E TECNOLOGIA BRASILEIRAS}

\section{RESUMO}

A situação da operação de Parques Científicos e Tecnologia Brasileiros (STPs) levou à pesquisa de campo. Mesmo com a política pública de estímulo e apoio das associações, nada foi mapeado na disseminação de resultados (crescimento econômico e desenvolvimento regional). Este cenário instiga a questão: quais são as características de governança dos Parques de Ciência e Tecnologia brasileiros? A pesquisa de campo empírica foi desenvolvida, levando em consideração a possibilidade de replicação no registro dos critérios de escolha nos casos múltiplos e nos detalhes da pesquisa e na coleta de dados. Oito STPs (TECNOPUC - Porto Alegre, Valetec - Novo Hamburgo, Tecnosinos - São Leopoldo, Unicamp, CIATEC e TECHNOPARK - Campinas, Rio Park - Rio de Janeiro e SergipeTec) participaram da pesquisa. Os resultados e as considerações sobre a questão da pesquisa podem ser inferidas a partir da pouca eficácia da governança (sem indicadores de desempenho qualitativos ou quantitativos), possivelmente devido as tensões caracterizadas por elementos como a heterogeneidade nas características das organizações que fazem parte dos STPs, falta de consenso sobre os objetivos comuns, forças de pressão e influências que afetam a obrigação, padrões de não conformidade e preferências pessoais e organizacionais. As relações de liderança defendidas pelo governo e / ou as empresas podem influenciar negativamente o desempenho do STP como um todo.

Palavras-chave: Desenvolvimento Econômico Regional; Parques de ciência e Tecnologia; Governança; Eficácia. 


\section{PRINCIPALES CARACTERÍSTICAS DE LA GOBERNANZA EN LOS PARQUES CIENTÍFICOS Y TECNOLÓGICOS DEL BRASIL}

\section{RESUMEN}

La situación de la operación de los Parques Científicos y Tecnológicos de Brasil (STPs) llevó a la investigación de campo. Aun con la política pública de estímulo y apoyo a las asociaciones, no se ha hecho ningún mapa de la difusión de los resultados (crecimiento económico y desarrollo regional). Este escenario instiga la pregunta: ¿Cuáles son las características de gobierno de los Parques Científicos y Tecnológicos de Brasil? Se desarrolló una investigación de campo empírica, tomando en consideración la posibilidad de replicación mediante el registro de los criterios de elección en los múltiples casos y los datos de investigación y la recopilación de datos. Ocho STP (TECNOPUC - Porto Alegre, Valetec - Novo Hamburgo, Tecnosinos - Sao Leopoldo, Unicamp, CIATEC y TECHNOPARK - Campinas, Rio Park Río de Janeiro y SergipeTec) participaron en la investigación. Los resultados y consideraciones sobre la pregunta de investigación permiten inferir la poca efectividad de la gobernabilidad (sin indicadores de desempeño cualitativo o cuantitativo) es posiblemente causada por tensiones caracterizadas por elementos como la heterogeneidad en las características de las organizaciones que forman parte de STPs, objetivos, fuerzas de presión e influencias que afectan a los fideicomisos, estándares de no conformidades y preferencias personales y organizacionales. Las relaciones de liderazgo defendidas por el gobierno y / o las empresas pueden influir negativamente en el desempeño del STP en su conjunto.

Palabras clave: Desarrollo económico regional; Parques Científicos y Tecnológicos; Gobernancia; Eficacia.

\footnotetext{
${ }^{1} \mathrm{PhD}$ in Regional and Urban Development from the University Salvador - UNIFACS. Professor of Catholic University of Salvador - UCSAL, Jorge Amado University Center - UNIJORGE and Faculdade DeVry | Ruy Barbosa. Brasil. Email: miltonsampaiofilho@ gmail.com

${ }^{2} \mathrm{PhD}$ in Management from the Federal University of Minas Gerais and École des Hautes Études Commerciales de Montréal, Canadá. Professor and Researcher at Salvador University and Bahia State University. Assistant Master Coordination Administration at the University Salvador. Brasil. E-mail: jair.santos@unifacs.br
} 


\section{INTRODUCTION}

The project analysis of Science and Technology Parks around the world presents three main reasons for its implementation as a regional development strategy: (a) creation of new jobs in new industries; (b) the need to engage in high-tech and market; (c) creating synergies between companies and industries.

The same studies point out that the three main reasons for STPs implementation as a regional development strategy partly explain a high rate of failure as its economic growth objectives (primary outcome) and regional development (secondary outcomes):

STPs are formed by actors from civil society organizations, governments (different levels), higher education institutions and / or research centers, and can form a network. This requires synergistic relationships that are highly complex in its confrontation of instabilities for consolidation and maintenance and also an ongoing process of negotiations and alignment of all stakeholders interests. Otherwise, there is the context for a destabilized network and possible damage to the expected results. Keeping the interests of all stakeholders aligned with the interests of the actorbuilder network requires a lot of persuasion and conviction. Decentralization motivated by the interaction of different actors (public or private) network requires another approach: the need to encourage and facilitate socioeconomic interactions and policies between different actors in order to deal with problems.

Governance interorganizational networks indicate that the unit or object of analysis are the networks, not relations involving networks. Interorganizational networks where governance occurs are seen as institutional interaction arenas, that provide rules, standards, practices and discourses that shape actions of the actors and create patterns of interaction. Santos (2003, p. 334) alerts that organizational networks function as a strategic tool with two facets: on the one hand they promise balance and stability to participants, on the other they limit the movement of their elements by membership rules and other commitments. This occurs when the network components draw attention or reframe those who try to act or are acting as established by the network, thus, limiting the flexibility to adapt and survive in a dynamic environment.

Taking advantage of the shortage of field research mapping Brazilian reality and specificity of science and technology parks in the Brazilian geographical context, it worked with the research question insead of hypotheses. The exploratory research allowed a broader investigative look at governance and management practice in Brazilian
STPs: What are the main governance characteristics of Brazilian science and technology parks?

The formulation of the research question in this qualitative research allowed to clarify assumptions of the theoretical analysis framework as well as priority issues on which the researchers wanted to know.

The article was structured starting with the introduction, which is made of the announcements subject, presents the research question and the linked purpose. The theoretical framework addresses a contextualization about governance in interorganizational networks. The mapping of a definitory statement proposed a multidisciplinary type of governance in interorganizational networks and indicates instability on the subject. The purpose of this topic is to understand the types, properties and analysis processes of governance networks. There is an academic interest for a multidisciplinary theoretical perspective of organizational relationships and their impact on development. The following is the methodology, guiding the collection of field data, analysis and discussion of the results and finally conclusions.

\section{GOVERNANCE INTERORGANIZATIONAL NETWORKS}

\subsection{Definitory Statement of Interorganizational Networks}

The study and conceptualization of networks in the eyes of Organizational and Interorganizational Studies (Kenis \& Schneider, 1991; Santos, 2003; Galaskiewicz, 2007; Provan \& Fish, 2007; Lewis, 2011; Klijn \& Koppenjan, 2012) comprises networks as vehicles for services and implementation of research. It is the effective exercise of policy-oriented issues of actor coordination, the interconnection of complex services and the effectiveness of mechanisms for achieving results through the creation and supply of products, that constitutes the network.

There are broad definitions of a network as "a set of nodes and set of ties representing some relationship or lack of relationship between us," the content of the relationship between us is "limited only by the imagination of the researcher" (Brass et al., 2004, p. 795), including in its proposal a variety of forms of cooperation such as joint ventures, strategic alliances, partnerships and consortia.

\subsection{Network Type Prospects}

This research adopts a defining statement drawn from Kilduff and Tsai's research (2003) and the level of analysis in which network is a form of governance: a network is made up of a group of three or more organizations linked through multilateral ties 
generally formally established (instead of occurring by chance) and managed (ruled) in order to facilitate the achievement of a common goal. Thus, conceptual mapping (Faulkner \& Rond, 2000; Galaskiewicz, 2007; Galaskiewicz \& Wasserman, 1994; Kilduff \& Tsai, 2003; Monk \& Contractor, 2003) considers that (a) networks can be seen as individual organizations (level analysis each actor or network node) on a micro-level analysis and (b) networks can be seen as a whole on a macro-level analysis. This research adopts the approach of Fish and Provan (2007): Studies on the interactions within the network as a whole: understand the properties and characteristics of the network as a whole.

\subsection{Properties and Analysis Process for Interorganizational Networks}

The bibliometric mapping prepared by Provan and Fish (2007) theoretical framework and used in this study, points out that the properties evaluated for networks as a whole are adaptations of the properties of organizational networks and processes: (a) structure; (b) development; (c) results and (d) governance.

The results of the network structure researchs suggests that both its general structure and the positioning of each organization influences the management of information and knowledge as transmitted by its members (Lipparini \& Lomi, 1999). The density of bonds tends to increase over time (Venkatraman \& Lee, 2004). Although the centralization facilitates the integration and coordination, density and centering can not be maximized simultaneously (Provan \& Milward, 1995). Provan and Sebastian (1998) found that the effectiveness of the whole can be explained by the intense integration of subnets (or cliques). All studies show that although the structure of relationships between members is the most often studied aspect, is strongly dependant on the decisions of its governance.

Network development can be seen as the result of using resources, rules and standards given to boost such development (Sydow \& Windeler, 1998). These rules and regulations depend on the knowledge of the mechanisms, meanings, goals and values of all the comprised organizations (Lipparini \& Lomi, 1999; van Raak \& Paulus, 2001).

The effectiveness of the network results involves analysis of the efficacy of the companies' results and the efficiency of the inter-organizational learning. Analysis in terms of the effectiveness of the results to society, indicates that interorganizational networks do not always have positive results. Under certain conditions, a cooperative network can have negative effects on the whole economy (eg, as in the case of agreements). It may become a structural source of competitive advantage between organizations (Soda \& Usai, 1999) or between regions (Grabher, 1993).
Human and Provan (2000) found that the continuity of the networks was strongly dependent on the internal and external legitimacy beyond the support in the early stages of evolution. They concluded that those formally constructed (and unstructured from previous relationships) are more likely to fail.

Governance is a critical factor that influences the previous three. Networks can be a superior mode of governance, but need to be better understanding of how they are governed.

\subsection{Governance Interorganizational Networks: Conceptualization}

The term governance may have different meanings. Clarke (2004), Machado Filho (2011) and Smith (2012) works provide a definition of governance, in contrast to the management. They also identify a coherent typology with a timeline, inferring on the needs of adaptation to the economic development since the industrial, services and knowledge economy, presented in three phases: the Agency Theory, the Stakeholder Theory and the Stewardship Theory.

The Agency Theory (Williamson, 1975, 1985, 1991, 1994, 1996), the dominant model of academic research, government regulatory frameworks and voluntary initiatives market, explains that a firm is a nexus of contracts between individual production factors having as conceptual basis of the control separation and ownership, for two distinct groups of interests need to be aligned in order to generate value for the business: on one side are investors, shareholders and owners, on the other side, other managers or agents that raise funds with investors for production. In this context, governance is understood as an instrument by which an order is achieved by different agents in an incomplete contractual relationship, settling any conflicts, to facilitate the achievement of common gains.

The Stakeholder Theory, by Freeman (1984), complements the approach of the Agency Theory expanding the vision of managers for external analysis environment: indicates who has stake (part / interest) in an organization is not only the shareholders (stockholders -USA or shareholders-England), but also all civil society that impact and are impacted by operations (involving aspects of environment and social responsibility). Friedman and Miles (2002), Blattberg (2004) and Clarke (2004) point out that in this approach the organization is a set of arrangements and multilateral agreements of the enterprise interdependence and its stakeholders and its governance is concerned with stabilizing the balance between social objectives and economic and between individual and collective goals.

The Stewardship Theory, by Donaldson (1990a, 1990b) and Barney (1990, 1991) deconstructs the division between agents and shareholders and the 
importance of their conflicts of interest: employees, managers, executives and company CEO constantly seek the best for the company and for themselves, the individual and collective interests are fully interconnected, managers can choose to act as agents or principals.

The Agency Theory, as summarized in Figure 1 , is presented as an alternative form of management of economic activities and an interaction between market and hierarchy. Stakeholder Theory guides a balance between the need to look at the market and continuity. In the perspective of Stewardship Theory, governance in organization network (formed by independent organizations and, in general, they are essentially cooperative ventures) is characterized as the design of the structure and organization of elements and internal coordination of networks.

The Stewardship Theory, among the three approaches is the closest that presents the operational reality of a network. It is also the most criticized by the disbelief of full alignment of individual and collective interests, thus requiring more specific rules and monitoring.

Figure 1 - Governance Concept

\begin{tabular}{|c|c|c|c|}
\hline ECONOMY & THEORY & AUTHOR - YEAR & GOVERNANCE CONCEPT \\
\hline Industrial & $\begin{array}{l}\text { Agency } \\
\text { Theory }\end{array}$ & $\begin{array}{c}\text { Williamson }(1975,1985 \\
\text { 1991, } 1994,1996) \\
\text { OCDE }(1987,1996)\end{array}$ & $\begin{array}{l}\text { A system in which corporations are directed and } \\
\text { controlled, with the distribution of rights and } \\
\text { responsibilities among different participants agents } \\
\text { as the board, managers, shareholders and other } \\
\text { stakeholders, in an incomplete contractual } \\
\text { relationship, settling any conflicts. } \\
\text { Aims to guarantee the creation of value for the } \\
\text { business and its distribution to shareholders }\end{array}$ \\
\hline Services & $\begin{array}{c}\text { Stakeholders } \\
\text { Theory }\end{array}$ & $\begin{array}{c}\text { Freeman (1984) } \\
\text { Friedman \& Miles (2002) } \\
\text { Blattberg (2004) } \\
\text { Clarke (2004) }\end{array}$ & $\begin{array}{l}\text { A system in which the organization is a set of } \\
\text { arrangements and multilateral agreements } \\
\text { interdependence of the enterprise and its } \\
\text { stakeholders; They are directed and controlled the } \\
\text { distribution of rights and responsibilities among the } \\
\text { participants and the Council, managers, } \\
\text { shareholders and other stakeholders. } \\
\text { Aims to ensure the generation of balanced value } \\
\text { between the look of the market (for the business } \\
\text { and its distribution to shareholders) and social } \\
\text { continuity (with all stakeholders of society that } \\
\text { impact and are impacted by operations involving } \\
\text { environmental aspects and responsibility social). }\end{array}$ \\
\hline Knowledge & $\begin{array}{c}\text { Stewardship } \\
\text { Theory }\end{array}$ & $\begin{array}{c}\text { Donaldson (1990a, } \\
\text { 1990b) } \\
\text { Barney (1986, 1990, } \\
\text { 1991) } \\
\text { World Bank (1992) } \\
\text { Donaldson \& Davis } \\
\text { (1991) } \\
\text { Davis, Schoorman, \& } \\
\text { Donaldson (1997) } \\
\text { Albers (2005) } \\
\text { Theurl (2005) } \\
\text { Provan \& Kenis (2008) } \\
\text { Barney \& Hesterly } \\
\text { (2008) }\end{array}$ & $\begin{array}{l}\text { Oriented system to generate value for the } \\
\text { organization as a whole (and not only for } \\
\text { shareholders). managers can choose to act as agent } \\
\text { or principal (employees, managers, executives and } \\
\text { CEO constantly seek the best for her and for } \\
\text { themselves, the individual and collective interests } \\
\text { are fully interconnected). }\end{array}$ \\
\hline
\end{tabular}

Source: Prepared by the authors of this research (2014).

It is understood that governance has a set of internal and external mechanisms to harmonize the relationship between the principal (shareholders) and agents (managers), orients and guides which and how relevant decisions to a network level as a whole are taken - decisions to achieve important goals, 
maintaining key relationships and providing feedback and who makes the decisions. In order to give overall direction to the business or group that has been administered, and monitor and control the executive actions of the administration must meet the legitimate expectations for accountability and regulation, with interests beyond corporate boundaries. Governance involves the business rules of the network game, rules for decision-making, monitoring, control, definition of incentives and sanctions for the network as a whole and its participants. Rules implemented by people, managers responsible for the effectiveness of the collective.

\subsection{Governance Interorganizational Networks: Methodology}

Objectives and needs of these actors may even conflict with the objectives of the network. For these reasons, the shared governance model is often difficult to maintain, and more likely to run on networks with few members and involving mutually dependent organizations with complementary and compatible goals (Olson, 1999; Park, 1996; Provan, 1994)

In studies of interorganizational networks, the term governance is adapted to the context of organizations performances and has its concept changed as the context, evolving into a broader view of the economy. Magnifies questions about why and under what conditions an organization should opt for the formation of a network instead of the hierarchical structure or market and increases its complexity.

Olson (1999), Park (1996), Provan (1994), Provan and Kenis (2008) developed derived propositions of empirical research, identifying three basic models of governance in interorganizational networks: shared governance, governance with leading organization and governance through network administrative organization or trilateral governance.

The simplest model is Participant-Governed Networks (shared governance), in which groups of organizations work collectively as a network, but do not have a formal and unique management structure. Governance takes place through meetings of undertakings representatives or even informally, through the actions of those who have an interest in the success of the network (Olson, 1999; Park, 1996; Provan, 1994).

The problem with this model is that, although it has a strong ideological appeal (due to the idea of participation) is generally not very effective because it depends on actors who have many other commitments of time and resources in their own organizations (Provan \& Kenis, 2008).

A second governance model is called Lead Organization-Governed Networks, which typically occurs in vertical relationships, client-supplier, in which there is a larger and more powerful organization and a set of smaller and weaker firms (Olson, 1999; Park, 1996; Provan, 1994; Provan \& Kenis, 2008).

The activities and key decisions are coordinated by a member who acts as a leader and manager of the network, facilitating the activities of the participants in their efforts to achieve the objectives of the network. The strong point of this governance model is the efficiency and legitimacy provided by the leading organization. One limitation is the fact that this organization can try to impose their own agenda and dominate the other participants in the network, causing resentment and resistance. This can also lead participants to a loss of interest in the network's goals, focusing exclusively on your individual goals, undermining the viability of the network (Provan \& Kenis, 2008; Windeler, 2003).

The third model of governance is called by Provan and Kenis (2008) as Network Administrative Organization (NAO). Park (1996) uses the term trilateral governance. The three authors believe that this model is a consequence of networks inefficiency with shared governance and the problems of domination and resistance networks with leading organizations.

A separate management organization composed of professional agents is created in order to manage the network and its activities, to monitor the behavior of the parties, manage the process of collective decision-making, coordinate and sustain the network. Such an entity is not a new firm or agency, established to manufacture their own goods or offer their services, but an integrated management office (Olson, 1999; Park, 1996; Provan \& KENIS, 2008).

\section{RESEARCH METHODOLOGY}

The strategy of exploratory research field adopted was the multiple case study. Yin (1984, 1993), Stake (1978, 2000), Bryman (2004), George and Bennett (2005), Gerring (2007) defend that it is a research strategy of applied social sciences that aims to investigate a contemporary phenomenon within its real life context to identify causal relationships, identify without measuring the variables.

Yin (1984, 1993), Stake (1978, 2000), Bryman (2004), George and Bennett (2005), Gerring (2007) converge in explaining the logic that governs the strategy of this kind of research is not sampling but replication. Each case should be selected according to the following estimates: (a) expect to find similar results in the various units investigated: replication itself or (b) expected results due to different factors previously anticipated by the investigator: theoretical replication.

In this research, by its exploratory character and few existing documentation on the Brazilian reality of governance in STPs, similarities and differences or characteristics are the result of field research. Our main concern was to ensure replication for recording the 
criteria for selecting the multiple cases and the interactive search details with triangulation of data collected performed.

As the initial response rate to the online questionnaire was only three (TECNOPUC - Porto Alegre, UNICAMP - Campinas and SergipeTec Sergipe), it was decided to establish contact with the representatives of the three respondents. These were the seeds of a multiple case chain. The other five contacts (Valetec - Novo Hamburgo, Tecnosinos - Sao Leopoldo, Rio Park - RJ, CIATEC and TECHNOPARK, both in Campinas) were made by the personal intervention of the initial respondents managers. We used the approach in chains with a random sample of participants (network design site).

The triangulation method refers to the collection of data using different methods and sources in order to increase the reliability of the study. Data collection for this study aims to explore, define and justify the case study. The methods are: (a) qualitative interviews; (b) document analysis and (c) comments. Such qualitative methods are chosen to provide access to complex issues that are not normally covered by quantitative methods (Buckle, Dwyer, \& Jackson, 2009).

The documentary analysis allows contrast the information and knowledge acquired from the interviews. The observations are based on formal and informal conversations with the administration and with network participants, in contrast to the information gathered in the interviews, the accessed documents and observed interactions.

The type of qualitative interview chosen for this study is semi-structured because that makes it possible to use interviews and arrange them according to the session dynamics (Kvale \& Brinkmann, 2009). There were forty interviews (average of five per STP) involving strategic management, tactical management, operational, business managers installed in STPs.

The authors conducted a qualitative analysis of the interviews extracts. Analyses were coded according to the concepts mentioned in theory and in order to respond to the formulation of the problem. This means that the knowledge and the information gathered is related to how the governance processes were established as the core training manager occurred and how the STP was structured and managed in the case studies. The encoding data was reiterated several times to adjust the results of case studies to theoretical and problem formulation.

\section{ANALYSIS AND DISCUSSION OF RESULTS}

Due to the inherent difficulties of data collection, this research was limited in scope to multiple case studies (eight STPs). Multiple case studies do not represent a sample whose results would be generalizable for a population, a statistical generalization. But it allows to generate theoretical propositions from a particular set of results, that are applicable to other contexts, in a strategy of replication, either by recording the criteria of choice of the multiple cases or by the details of the interactive research with triangulation of the data collected.

Access to the updated list showed another severe and paradoxical limitation: in a cycle of innovation-intensive and knowledge-intensive business, it silences requests for access to public information, highlighting points of improvement, minimally on the criterion of transparency of governance.

The same scenario has already been reported of scope limitations (studies of multiple cases), restrictions of access to information on Brazilian STPs and the impossibility of result generalization instigates more questions than certainties.

\subsection{Account of the history of personal / professional life}

It was found that in STPs with more Science Parks- SPs features arise indications of involvement, commitment, belonging and concern for the STP. Monitor progress, stagnation or even retrogression in research and its possible consequences on the continuity of the STP. There is no indication of the individual contributions importance in the context of STP organizations involvement to contribute to the continuity in a highly competitive economic environment.

The origin of the participants is related to their graduation or post-graduation, participation in scientific initiation projects, preparation of business plans. Teacher leadership helped the construction of the students future vision. These participants permanence in SPs has a longer duration when compared to participants of Technology Parks-TPs.

It was found that respondents in Technology Parks-TPs showed less involvement and commitment, they evaluate the world in an utilitarian and pragmatic way. They also have strong business relationship, are concerned with the market changes and the development of rapid acceptance and sales solutions. The perception is commitment and duties with the organization in which they are employed. Monitor progress, stagnation or even retrogression of market opportunities and how their work can be taken advantage off.

The origin of its participants is related to short-term research projects or previous experiences in market companies. They understand that TPs are research centers structured by the company they work for business incubation.

\subsection{Definition of STP}


When actors or participants in Brazil define a science park, they tend to do it formally but also with concearn as if they were in a selection process, resorting to paper documents or electronics. They built the explanation with words like: research center, university, research grants, support agencies, support companies and publications.

These results show alignment to the literature when they highlight features or basic criteria such as having formal links with the university or other educational and research institutions and allow the formation and growth of technology-based companies and other organizations that are also located on site. But nothing makes reference to the stimulus of technology transfer, promotion of actions aimed at increasing the capacity of businesses and other enterprises that reside on site.

When actors or participants in Brazil define a technology park, they tend to do it informally; is as if describing the company where they work. They use keywords such as: business incubators, microenterprise, government support, access to finance, profit.

The responses indicate a formal knowledge, but not internalized when compared to the literature about what a STP is. Even in literature, there is a lack of STP concept of wider and universal application.

\subsection{Expected results of a STP}

Regardless of the STP, the speeches show a well targeted stakeholder interests represented by the interviewees.

Members of universities or research institutes stressed that they commercialize results of academic research, expanding the sources of funding, broadening institutional mission and expanding labor market for researchers and students.

Entrepreneurs and academics entrepreneurs (incubated companies) highlighted that they use results of academic activities and research so as to enhance their own R\&D business activities, maximizing financial returns, accessing qualified human resources and creating jobs. Some business owners reported the interest and support of funding agents and venture capital to invest in new technology-based companies with high and fast economic growth potential. Development agencies were not included in the face of field work restrictions. Maybe that's why it wasn't noticed in the speech analysis references to revitalizing economically depressed regions or promoting regional development.

No statements about the knowledge of the STP as a whole was done by the respondents. They show difficulty or lack of identification about STP's priorities and capabilities as a public policy tool. This can maximize nonadherence as development inductor to local or regional reality. Such considerations are illustrated by extracts from the speeches of the following interviews.

The analysis up to this stage to suggest that STPs are considered inducers of academic projects, when CPs or inducers of new projects, when TPs.

The practice shows no concept of internalization and possibly consequences in the management guidelines. There is no counterpart to the speech, metrics that monitor the return on economic and social investment of STPs.

\subsection{Effectiveness of the STP results}

Initially, the goal was to understand the effectiveness of the STP results either by the efficiency of the structure and governance, whether the effectiveness of inter-organizational relationships, involving learning the STP actors. The following points were analized: the existence of common goals for the STP as a whole, the existence of an agreement, consensus on the results to be achieved by the STP, the difficulty in doing so, and the perception of a governance model.

STPs's goals according to stakeholders are:

a) universities or research institutes: commercialize academic research results, broadening the sources of financial resources, broadening institutional mission, expanding labor market for researchers and students

b) business people and academics entrepreneurs (incubated companies): using results of academic activities and research to enhance their own R\&D and business activities, enhancing financial returns, accessing qualified human resources, creating jobs, investing in new technology-based companies with high and fast economic growth potential and financial returns.

Such objectives are not related to metrics (performance indicators established measurement method) on goals within specific periods, whether quantitative or qualitative. Even without the literature cited in the survey, this gap in the monitoring process is misaligned with the best management practices and governance.

Complaints arose involving difficulties in qualified people, sometimes requiring migration experts from other states or even countries, not exploitation of regional development potential of new products and services and the difficulty of exchanging knowledge mainly management technologies.

Complaints about the difficulties of achieving the specific results of stakeholders is in line with the literature. Luger and Goldstein (1991), Castells and Hall (1994) and Bass (1998) point out that the three main reasons for the implementation of STPs partly explain a high failure rate of STPs as its economic 
growth objectives (primary outcome) and regional development (secondary outcomes): (a) creating new jobs in new industries presupposes previous investment in professional training, or requires experts migration; (b) interest to engage in high-tech market concentrating high-growth industries in poorer regions economically. In addition to requiring the assumption of the previous item, it reveals the inattention to the difference between locational aspects of manufacturing products agglomeration economies and the need to adapt to an economy of knowledge and (c) create synergies between the business and industry requires investment in means of communication facilitating the exchange of knowledge.

The lack of metrics makes the attempts to solve the claims unsubstantiated and increases the difficulty of requesting support to change public policies. Also, that makes it harder to demonstrate negative impact in the absence of return over investment.

Respondents, possibly due to anonymity, showed concern for the lack of evidence on STPs initiatives on the economy, society and regional environment. The reports demonstrate knowledge about the dependence on public and private financial resources and the difficulty of achieving STPs continuity. They understand that Brazilian STPs, regardless of location or level of development, are presented more as an excessive political argument to the implementation of a physical structure to support enterprises, better use of the land (real estate) than as possible inducers of growth and economic development through better university-businessgovernment interaction.

\subsection{Governance: definition and main actors}

As a possibloe consequence of the lack of STPs common goals, the understanding of what is governance and which actors are responsible for it appears to be confusing and even non-existent. Three observations:

a) There is an understanding about governance, possibly by the strong bond with the specific objectives to specific stakeholders, without common general objectives, that leads to concept dissociation. Despite knowing what governance is, the respondents make no conections to PTCs day by day activities.

b) Due to the strong bond to specific stakeholders, the respondets understand the concept of working network and interorganization network, but consider that their daily activities are contrary to this interelational exercise;

c) It is understood that there is park management, following established guidelines, but apparently poorly revised, by councils or committees: steering committee, top board, board of directors or advisory board. Even this structure is not fully communicated.

The literature induces the understanding that between the three presented theories on governance, stewardship would be the most aligned. The proposition of a STPs governance model is based on the governance conceptual foundations of a organizations network with distinct interests that need alignment for better effectiveness. By having direct or indirect public funding, they should consider environmental and social interests.

Empirical research shows another perspective: due to the lack of common goals, the theory of agency is the most current one: each organization with its representative stakeholder establishing the guidelines.

When stakeholders are members of universities or research institutes, they stress the commercialization of academic research results, broadening of the sources of funds, increased institutional mission, expanding labor market for researchers and students. When business and academic entrepreneurs (incubated companies) highlighted that they use results of academic activities and research to enhance their own R\&D business activities, enhance financial returns, access qualified human resources and create jobs. Some business owners reported the interest and support of funding agents and venture capital to invest in new technology-based companies with high and fast economic growth potential and financial returns.

Nothing appears in the speeches covering the stakeholder theory: relationships with external stakeholders (suppliers, society, government, shareholders, customers, consumers, creditors) and internal (employees, managers, owners). Even less when it comes to the stewardship presented by the literature as having greater adherence to STPs.

Reviewed by the Agency Theory, the relationship between the parties is established contractually to develop activities that meet the main interests, involving power delegation for decision making by the agent. Governance guidelines are established to face agency problems and for strategic decision makers: monitoring and controling mechanisms to reduce these differences.

As a consequence, the Stewardship Theory is absent, although literature recommends it. Governance in this theory is a continuous process to accommodate different interests, common troubleshooting and performing cooperative actions; providing guidelines to collective action, coordination and monitoring of internal and external networks of a STP; guiding the degree of hierarchy and democratization of the organizations decision-making structures, collaborative agreements not in hierarchical relations can be articulated; guiding the construction of organized networks; management of interactions; regulatory 
systems and mechanisms for coordination and negotiation between social actors. This would allow the implementation of its principles (Organization recommendations for Economic Co-Operation and Development (OECD): transparency (disclousure), equity (fairness); accountability and corporative responsibility (compliance).

It is characterized by a strong bureaucracy and with many documentation manuals. The action and effective implementation of the common results is compromised by lack of investment in new people management methodologies (processes and technologies) and, consequently, little personnel training for collaborative work.

The analysis up to this stage suggests that the absence of a platform that integrates common goals and consequently performance integrated metrics, prevent a reasoned response. Certainly STP actors present results, but nothing related to the effectiveness of STP as a whole. There is a high possibility of low scientific, economic, social and environmental STP return, as they admit to intentionally not work collaboratively. The pressure for specific outcomes leads to networking resistance.

The analysis and brief discussion of the results lead to another question to continue the research: What are the main barriers to the effectiveness of governance in Brazilian science and technology parks? It may indicate a complex challenge: to implement a governance structure and guidelines in an environment in which its actors confuse governance with management. Empirical research allows us to infer that the main barrier is probably the concepts nonintrojection, principles and practices of governance. Without clearly communicated and periodically reviewed strategic guidance, the results may not even be classified as effective, compromising the stability of STPs.

\section{CONCLUSIONS AND RECOMENDATIONS}

When starting this research, it was understood that STPs are made by actors of civil society organizations, governments (different levels) and higher education institutions and / or research centers. They could form an interorganization network where governance can play a strategic role in the synergistic relationships of high complexity in its confrontation of instabilities for consolidation and maintenance.

The considerations on the research questionWhat are the main characteristics of the governance in Brazilian science and technology parks? - indicate a misalignment of literature: the Brazilian STP actors do not recognize the existence of governance to guide strategic, tactical and operational actions.

Empirical research has another bias: due to the lack of common objectives, agency theory is the one that most presents itself in the governance management: each organization with its representative stakeholder establishing the guidelines: science parks with the university, technology parks with the Companies.

Diverging from literature, the results perceived in STPs are directed to its main stakeholders: science production and technology commercialization. There are expected objectives in each stakeholder. These same goals are not accompanied by metrics (established performance indicators, benchmarking method) on goals to be achieved in a given time frame, either quantitative (how to do) or qualitative (how to behave or how satisfied the beneficiaries are). Even without specific literature cited in the research, this process monitoring gap is out of alignment with best governance practices.

Given the arguments on how STP projects are sold, the most consistent type of governance would be Stewardship Theory. The lack of common objectives for STPs as a whole, the mix of governance and management understandings can adversely affect the implementation of their principles of transparency (disclousure); Fairness; Accountability and corporate responsibility (compliance).

It seems that the argument of being inducers of regional development is more political, detached from internal communication and practices and external to STPs. They involve the difficulty or lack of priorities and capabilities identification on Brazilian STPs as an instrument of public policy. It is not explicit, thus misaligned from the literature, an integrated action of job creation; establishment of new businesses; facilitating the interaction between universities and companies located in the parks and promoting the diffusion of new or high technologies for the development of the region where they operate.

Nothing was said about common goals, which blended the specific objectives into a single strategic platform. There is a lack of performance indicators that validate the various impacts resulting from the implementation of STPs in Brazil.

The possibility of low scientific, economic, social and environmental returns of the STP as a whole is great since they admit not to work intentionally in a collaborative way. The collection of specific results leads to the resistance to network.

As STP initiatives involve the provision of considerable public and private financial resources, the absence of performance evidence is troubling. There are no counterparts to the speech, metrics that monitor the return on the economic and social investment of STPs.

The dependence on the contribution of public resources that the STP projects demonstrate can not be justified as to the return on this investment, be it economic, social or environmental.

Brazilian STPs, regardless of location or level of development achieved, are more a political argument for the implementation of a physical support structure 
for companies, better use of land (real estate projects) than as possible inducers of sustainable economic growth and development trought better universitybusiness-government interaction.

The discourse on governance and on STP, after content analyzis, presents guidelines of instrumental rationality: proposes, applies, defends and reinforces the use of successful models, sells an idea of structures and relationships that can be guaranteed by agreements and contracts. With all the actor heterogeneity involved in Brazilian STPs and the superposition of functional (administrative, political, economic and social) charges with tactical and operational performance criteria that are not fully preestablished and in the face of governance guidelines that do not have common objectives to STPs as a whole, managers tend to perform governance in an overly bureaucratic bias.

The absence of a networked culture, the arena of conflicts arising from the heterogeneity of actors involved in a STP, the absence of a continuous cognitive, social and emotional qualification aimed at negotiating these conflicts can lead to ineffective execution (effectiveness understood by the conjunction of efficiency in the use of the intellectual and emotional energy from those involved and the effectiveness of the results obtained in line with the defined strategies).

Work operations on STPs can be well structured with clear procedures. But there is no point in an operation with structured procedures without defined strategies, clear objectives and people who can not establish collective learning connections.

The adoption of foreign models is still recommended. Adopting models involves copying processes and learning the work techniques. The effectiveness of this qualification may have an effect on interpersonal and interorganizational behaviors and relationships through principles and guidelines based on clear strategies, communicated, constructed in a participatory manner, simple operations and procedures.

These considerations contributed to the objective of characterizing governance in the context of Brazilian science and technology parks.

From this research, proposals can be made to broaden the knowledge of Social Science about STPs: how to work the guidelines and actions of governance so they can be understood as a new form of organization not e controlled xclusively by central units, but also distributed in the interaction of different actors

Another collaboration is outlined in Political Science's view of STPs: How to establish negotiating arenas, complementary political channels to traditional government channels to establish common goals through better interaction between different actors (government, public administrations and interest organizations)?
It was not the objective of this research to propose a general model capable of explaining the performance of STPs, since it involves a large number of factors that directly or indirectly affect the performance of STPs as a whole, expanding with the complexity of interorganizational relationships, participants' interdependence and mutual influences. There are other research questions that may contribute to the studyes of Organizational and Interorganizational Studies on STPs:

a) What is the change in the organizations performance and the STP as a whole to each new tenant association? The inability to compare actors' performance before and after joining them would be aligned: it understands STPs as networks and as vehicles for service delivery and research implementation.

b) What would be the effectiveness of a functional structure with three actor profiles in STPs governance strategic decision makers, operational managers and institutional relations managers? Actors recruited, selected and continuously qualified in cognitive, social (interpersonal relations) and emotional (behavioral) skills. Oriented to guide the continued negotiation of strategies, tactics and operations.

c) Are there certain STP structures more effective than others? For example, are STPs with fewer participants more effective than STPs with higher density of renters? Are there other structural properties that are crucial to the overall effectiveness of STP? How is the presence of structural holes? Are there other critical factors than those not contemplated in the literature? ANPROTEC's more effective action and partnership with Brazilian STPs and their nuclei of governance could enable continued monitoring of governance and STP performance in the short, medium and long term;

The hope is that the discussions and propositions stemming from the theory-empiricism of this study will contribute to the better effectiveness of STPs. That strategies and operations can be successfully performed by managers-leaders recruited and selected by the set of cognitive-social-emotional (behavioral) competencies and not only by protocol criteria.

It is recommended that regional development researchers who frame arguments and proposals for the realization of projects that contemplate characteristics, both of the region, and of the essential competences of strategists and executors should include the complexity of the topic in your searches. 


\section{REFERENCES}

Albers, S. (2005). The design of alliance governance systems. Köln (DE): Kölner Wissenschaftsverlag.

Barney, J. B. (1990, july). The debate between traditional management theory and organizational economics: substantive differences or intergroup conflict. Academy of Management Review, 15 (3), 382-393.

Barney, J. B. (1991). Firm resources and sustained competitive advantage. Journal of management, 17(1), 99-120.

Barney, J. B. ; Hesterly, W. (2008). Administração estratégica e vantagem competitiva. São Paulo: Pearson Prentice Hall.

Blattberg, C. (2004). From pluralist to patriotic politics: putting practice first. Oxford; New York: Oxford University Press.

Brass, D. J., Galaskiewicz, J., Greve, JH.R., \& Tsai, W. (2004) Taking stock of networks and organizations: a multilevel perspective. Academy of Management Journal, 47(6), 795-817.

Bryman, A. (2004). Social research methods. New York: Oxford University Press.

Buckle, J. L., Dwyer, S., \& Jackson, M. (2009). Qualitative bereavement research: incongruity between the perspectives of participants and research ethics boards, International Journal of Social Research Methodology, 13(2), 111-125.

Clarke, T. (2004). Theories of corporate governance. Nova York: Routledge.

Davis, J. H., Schoorman, F. D., \& DonaldsoN, L. (1997). Toward a stewardship theory of management. Academy of Management Review, $22,20-47$.

Donalson, L. (1990, july, a). The ethereal hand: organizational economics and management theory. The Academy of Management Review, 15(3), 369381.

Donalson, L. (1990, july, b). A rational basis for criticisms of organizational economics: a reply to Barney. The Academy of Management Review, 15(3), 394-401.

Donaldson, L., \& Davis, J. H. (1991). Stewardship theory or agency theory: CEO governance and shareholder returns. Australian Journal of Management, 16, 49-65.
Faulkner, D.O. , \& Rond, M. (2000). Perspectives on cooperative strategy. In D. O. Faulkner \& M. de Rond (Eds.), Cooperative strategy: 3-39. Oxford , UK: Oxford University Press

Freeman, R. E. (1984). Strategic management: a stakeholder approach. Minnesota: Cambridge University Press.

Friedman, A., \& Miles, S. (2002, january). Developing stakeholding theory. Journal of Management Studies, 39(1).

Galaskiewicz, J. (2007). Has a network theory of organizational behaviour lived up to its promises? Management and Organization Review, 3, 1-18.

Galaskiewicz, J., \& Wasserman, S. (1994). Advances in Social Network Analysis: Research from the Social and Behavioral Sciences. Newbury Park, CA: Sage

George, A. L., \& Bennett, A. (2005). Case studies and theory development in the Social Sciences. Cambridge, Mass: MIT Press.

Gerring, J. (2007). Case study research: principles and practices. New York: Cambridge University Press.

Grabher, G. (1993). The weakness of strong ties: the lock-in of regional development in the Ruhr area. In: Grabher, G. (Ed.). The embedded firm: London: Routledge. (pp. 265-277).

Human, S. E., \& Provan, K. G. (2000). Legitimacy building in the evolution of small-firm networks: a comparative study of success and demise. Administrative Science Quarterly, 45, 327-365.

Kenis, P. N., \& Schneider, V. (1991). Policy networks and policy analysis: scrutinizing a new analytical toolbox. In: Kenis, P. N., \& Schneider, V., Policy networks: empirical evidence and theoretical considerations. 25-59.

Kilduff, M., \& Tsai, N. (2003). Social networks and organizations. London: Sage Press.

Klijn, E.-H., \& Koppenjan, J. (2012). Governance network theory: past, present and future. Policy \& Politics, 40(4), 587-606.

Kvale, S., \& Brinkmann, S. (2009). Interviews. Learning the craft of qualitative research interviewing. USA: Sage Publications.

Lipparini, A., \& Lomi, A. (1999). Interorganizational relations in the Modena biomedical industry: a case study in local economic development. In: Grandori, 
A. (Ed.). Interfirm networks: organization and industrial competitiveness. London: Routledge, 120-150.

Machado Filho, C. P. (2011). Responsabilidade social e governança: o debate e as implicações. São Paulo: CENGAGE Learning.

Monge, P., \& R.; Contractor, N. S. (2003). Theories of communication. New York: Oxford Univ. Press.

OCDE - Organização para a Cooperação e Desenvolvimento Económico. (1996). The knowledge-based economy. Paris.

OCDE - Organização para a Cooperação e Desenvolvimento Económico. (1987). Science Parks and Technology complexes in relation to regional development, the organization for economic co-operation and development. Paris.

Olson, M. (1999). A lógica da ação coletiva. São Paulo: EDUSP.

Park, S. H. (1996). Managing an interorganizational network: a framework of the institutional mechanism for network control. Organization Studies, 17, 795-823.

Provan, K. G. (1994). Causal independence and subnetwork extraction in large belief networks. Stanford: Stanford University.

Provan, K. G., \& Fish, A. (2007). Interorganizational networks at the network level: a review of the empirical literature on whole networks. Journal of Management, 33(3), 479-516.

Provan, K. G., \& Kenis, P. (2008). Modes of network governance: structure, management, and effectiveness. Journal of public administration research and theory, 18(2), 229-252.

Provan, K. G., \& Milward, H. B. (1995). A preliminary theory of interorganizational network effectiveness: a comparative study of four community mental health systems.Administrative science quarterly, 40, 1-33.

Santos, J. N. (2003). A liderança no contexto das redes organizacionais. 2003. Tese (Doutorado)Universidade Federal de Minas Gerais - UFMG, Belo Horizonte.

Smith, V. P. B. (2012). Desafios socioambientais e os distintos tipos de governança. In: ENCONTRO NACIONAL DA ANPAD, 2012, Belém. Anais... . Belém.
Soda, G., \& Usai, A. (1999). The dark side of dense networks: From embeddedness to indebtedness. In: Grandori, A. Interfirm networks: organization and industrial competitiveness. London: Routledge. 276-302.

Stake. R. E. (2000). Case studies. In: Denzin, N. K., \& Lincoln, Y. S. (Ed.). Handbook of qualitative research. London: Sage, 435-454.

Stake. R. E. (1978). The Case study method in social inquiry. Educational Researcher, 7(2), 5-8.

Sydow, J., \& Windeler, A. (1998). Organizing and evaluating interfirm networks: a structurationist perspective on network processes and network effectiveness. Organization Science, 9(3), 265-284.

Theurl, T. (2005). From corporate to cooperative governance. In: Theurl, T. Economics of interfirm network. Tubingen: Mohr Siebeck, 149-192.

Van Raak, A., \& Paulus, A. (2001). A sociological systems theory of interorganizational network development in health and social care. Systems Research and Behavioral Science, 18, 207-224.

Venkatraman, N., \& Lee, C. (2004). Preferential linkage and network evolution: a conceptual model and empirical test in the U.S. video game sector. Academy of Management Journal, 47, 876-92.

Williamson, O. E. (1991). Comparative economic organization: the analysis of discrete structural alternatives, Administrative Science Quarterly, 36(2), 269-296.

Williamson, O. E. (1996). Economic organization: the case for candor. Academy of Management Review, $21,48-57$.

Williamson, O. E. (1985). The economic institutions of capitalism: firms, markets and relational contracting. New York: Free Press.

Williamson, O. E. (1975). Markets and hierarchies: analysis and antitrust implications. New York: Free Press.

Williamson, O. E. (1994). Transaction cost economics and organization theory. In: Smelser, N. J. ; Swedberg, R. (Ed.). The handbook of economic sociology: Princeton: Princeton University Press, 77-107.

Windeler, A. (2003). Kreation technologischer Pfade: ein strukturationstheoretischer Analyseansatz. Managementforschung, 13, 295-328. 
WORLD BANK (1992). Governance and development. Washington, DC: The World Bank. Disponível em: <http://documents.worldbank.org/curated/en/1992/0 4/440582/governance-development> Acesso em: 20 jun. 2014.
Yin, R. K. (1993). Applications of case study research. California: Sage Publications.

Yin, R. K. (1984). Case study research: design and methods.

London:

Sage. 